\title{
ELECTROCARDIOGRAPHIC CHANGES AFTER ANOXÆMIA AND EXERCISE IN ANGINA OF EFFORT
}

\author{
BY \\ COURTENAY EVANS AND GEOFFREY BOURNE \\ Received November 3, 1940
}

Significant changes in the four lead electrocardiogram occur in two-thirds of all cases with angina of effort. This investigation shows that anoxæmia or exercise causes a temporary abnormal change in the electrocardiogram and reduces the number of those with effort angina but with no electrocardiographic abnormality to about 18 per cent.

Details of the Anoxamia Test.-The subject reclines on a couch and a four lead electrocardiogram is taken, using chest leads IV R and IV F. A closefitting mask, having inlet and outlet valves and tubes, is strapped to the face. 10 per cent oxygen is inhaled from a rubber bag for three to five minutes. In some of the earlier experiments we used 12 per cent oxygen for ten or fifteen minutes, but it was found that 12 per cent oxygen did not produce anoxæmia sufficiently quickly.

After inhalation for two and a half minutes the tracing was taken with the inhalation continuing; it usually needed two minutes to take, and it was an advantage to have two operators, one to take the tracing and one to regulate the oxygen apparatus and change the leads. 100 per cent oxygen was then given for a minute and the mask removed; fifteen to twenty minutes later another tracing was taken.

The Exercise Test.-The subject walked rapidly up and down a long passage and, in many cases, a short flight of stairs was included. After five or ten minutes of this exercise, a tracing was taken. Usually in the anginal cases the exercise was continued until chest pain occurred. Very much more severe exercise was given to the control cases.

\section{RESULTS}

Control Group.-Ten controls consisted of seven normal, healthy medical students, two cases of well-compensated valvular disease, and one case of left mammary pain without organic heart disease. They showed no RS-T changes or $\mathrm{T}$ wave inversion. A diphasic $\mathrm{T}_{3}$ developed in one and the voltage of the $\mathrm{T}$ waves was reduced in five. The details were as follows: 


\begin{tabular}{|c|c|c|c|c|c|}
\hline \multicolumn{4}{|c|}{ Diagnosis } & Anoxæmia Test & Exercise Test \\
\hline $\begin{array}{l}\text { Left man } \\
\text { Mitral st } \\
\text { Aortic in } \\
\text { Normal } \\
\text { Normal } \\
\text { Normal } \\
\text { Normal } \\
\text { Normal } \\
\text { Normal } \\
\text { Normal }\end{array}$ & $\begin{array}{ll}\text { ry pain } & . \\
\text { is } & \ldots \\
\text { ppetence } \\
\ldots & \ldots \\
\ldots & \ldots \\
\ldots & \ldots \\
\ldots & \ldots \\
\ldots & \ldots \\
\ldots & \ldots \\
\ldots & \ldots\end{array}$ & $\begin{array}{l}\cdots \\
\cdots \\
\cdots \\
\cdots \\
\cdots \\
\cdots \\
\cdots \\
\cdots \\
\cdots \\
\cdots\end{array}$ & $\begin{array}{l}\cdots \\
\cdots \\
\cdots \\
\cdots \\
\cdots \\
\cdots \\
\cdots \\
\cdots \\
\cdots\end{array}$ & $\begin{array}{l}\text { No change } \\
\mathrm{T}_{3} \text { lower voltage } \\
\text { No change } \\
\text { No change } \\
\mathrm{T} \text { waves lower voltage } \\
\text { No change } \\
\text { No change } \\
\mathrm{T} \text { waves lower voltage } \\
\mathrm{T} \text { waves lower voltage } \\
\mathrm{T}_{3} \text { diphasic }\end{array}$ & $\begin{array}{l}\mathrm{T}_{3} \text { flatter } \\
\text { No change } \\
\text { No change } \\
\text { No change } \\
\mathrm{T} \text { waves higher voltage } \\
\text { No change } \\
\text { No change } \\
\text { No change } \\
\mathrm{T} \text { waves lower voltage } \\
\text { No change }\end{array}$ \\
\hline
\end{tabular}

Angina of Effort Group.-Twenty cases of angina of effort, in whom the four lead cardiogram showed no significant change, were tested. Six gave abnormal S-T and $\mathrm{T}$ wave responses to the anoxæmia test. Eighteen of these were also given the exercise test, and abnormal $\mathrm{S}-\mathrm{T}$ or $\mathrm{T}$ wave changes occurred in eight.

One case gave changes following anoxæmia and none after exercise. Three cases gave none after anoxæmia and $\mathrm{S}-\mathrm{T}$ and $\mathrm{T}$ wave changes after exercise. In those cases giving changes both after anoxæmia and exercise, three showed more marked changes after anoxæmia and five after exercise. Illustrations are shown in Figs. 1-3.

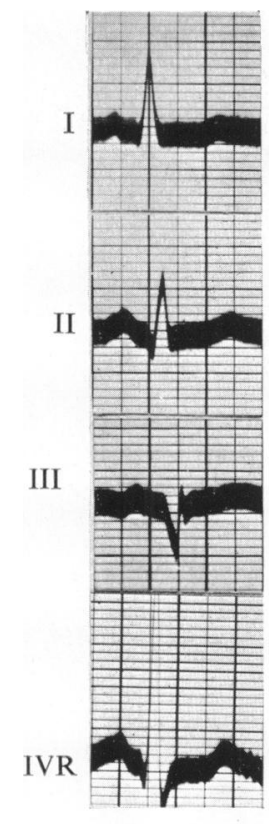

A

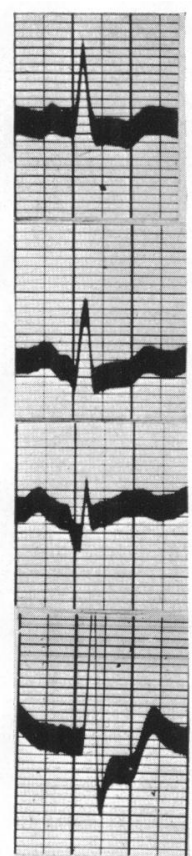

B

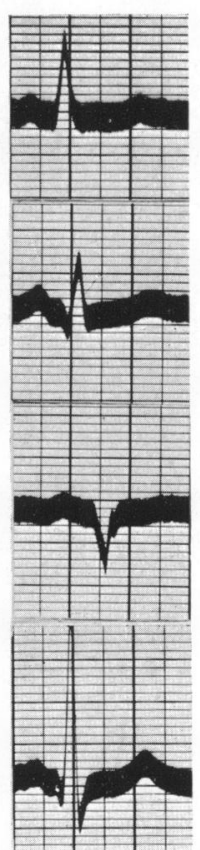

C

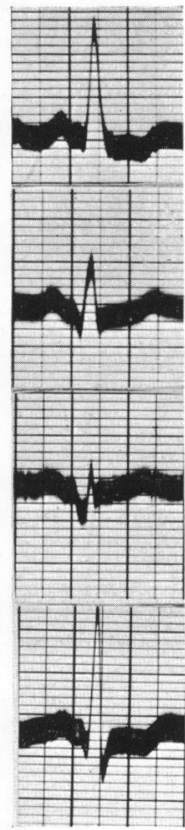

$\mathrm{D}$

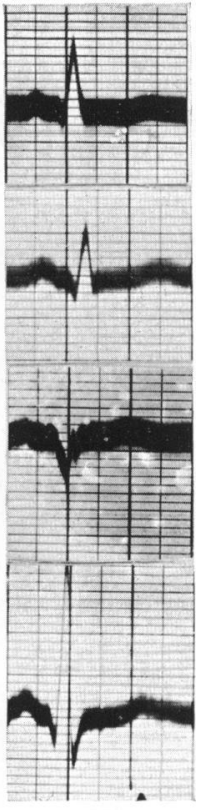

$\mathrm{E}$

FIG. 1.-(A) Resting electrocardiogram, with $Q_{3}$ doubtful. (B) After anoxamia; $T_{1}$ inverted, RS-T ${ }_{4}$ depressed and diphasic. (C) Recovery 20 minutes later. (D) After exercise, $\mathrm{T}_{1}$ and $\mathrm{T}_{4}$ diphasic, RS-T $\mathrm{T}_{1}$ and $\mathrm{RS}-\mathrm{T}_{4}$ a little depressed. (E) Recovery 20 minutes later. 


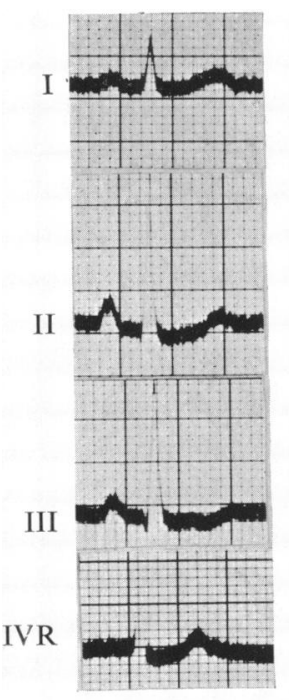

A

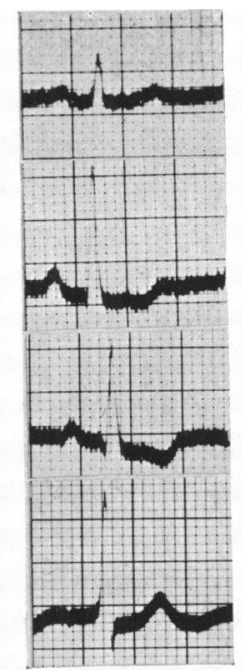

B

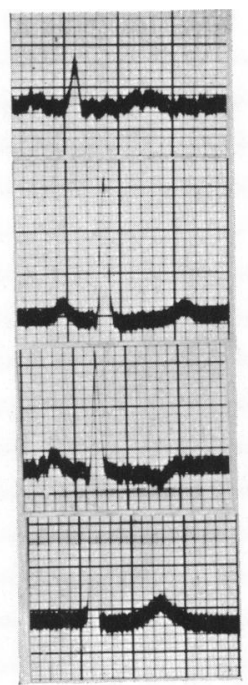

C

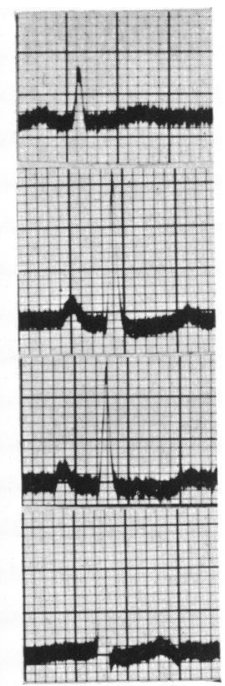

D

FIG. 2.-(A) Resting electrocardiogram. (B) After anoxæmia; $T_{2}$ and $T_{3}$ diphasic, RS-T $T_{4}$ depressed $1.5 \mathrm{~mm}$. (C) Recovery. (D) After exercise. (Note change after anoxæmia, but very little after exercise.)

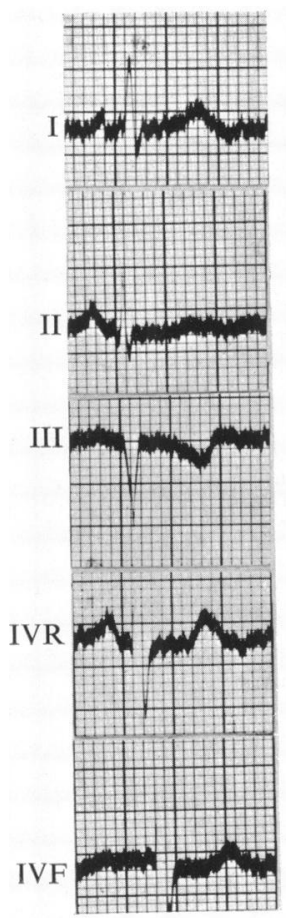

A

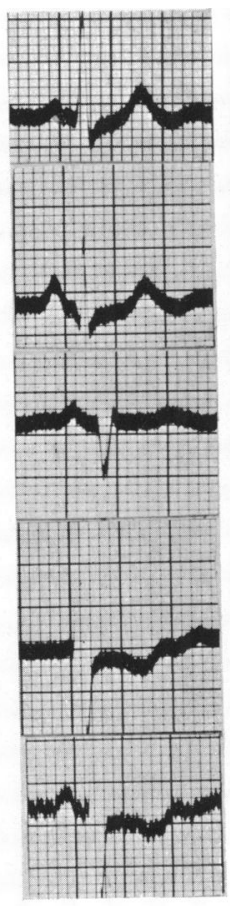

$\mathrm{B}$

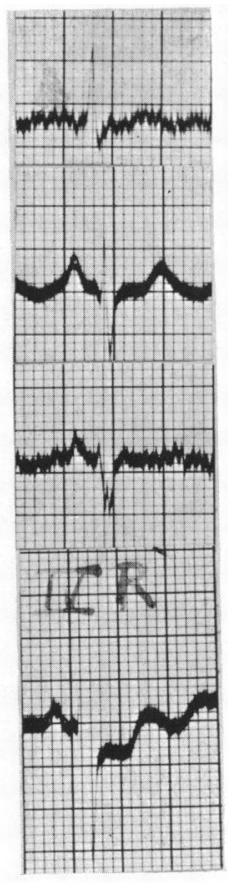

C
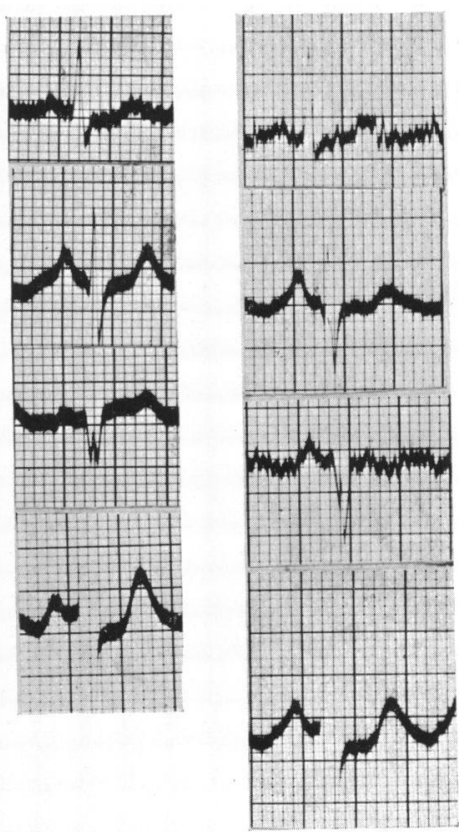

$\mathrm{E}$

FIG. 3.-(A) Resting electrocardiogram, left axis deviation, $T_{3}$ inverted. (B) After exercise, RS-T $T_{4}$ depressed and $T_{4}$ inverted. (C) Two months later, resting electrocardiogram shows depressed $\mathrm{RS}_{4}-\mathrm{T}_{4}$ and diphasic $\mathrm{T}_{4}$. (D) After anoxæmia. (E) After 20 minutes' rest. (Note change after exercise test and some deterioration in the resting tracing two months later; but very little change after anoxæmia.) 
To sum up: eleven cases gave no change after anoxæmia or exercise; nine showed some change after anoxæmia or exercise.

The $\mathrm{T}$ wave changes were, with one exception, associated with RS-T elevation or depression. Changes in the chest lead occur in a more exaggerated fashion than in the other leads. The details were as follows:

ANGINA OF EFForT

\begin{tabular}{|c|c|c|}
\hline Case No. & Anoxæmia Test & Exercise Test \\
\hline 1 & No change & No change \\
\hline 2 & $\mathrm{~T}_{2}$ flatter & No change \\
\hline 3 & No change & No change \\
\hline 4 & $\mathrm{~S}-\mathrm{T}_{2}$ depressed, less than $1 \mathrm{~mm}$. & No change \\
\hline 5 & $\mathrm{~T}$ and $\mathrm{R}$ lower voltage & Not done \\
\hline 6 & No change & No change \\
\hline 7 & No change & Not done \\
\hline 8 & $\mathrm{~T}$ waves lower voltage & No change \\
\hline 9 & No change & No change \\
\hline 10 & No change & No change \\
\hline 11 & No change & No change \\
\hline 12 & $\mathrm{~S}-\mathrm{T}_{2} \& \mathrm{~S}-\mathrm{T}_{4}$ depressed $2 \mathrm{~mm}$ & $T_{2}, T_{3}, \& T_{4}$ diphasic \\
\hline 13 & $\begin{array}{l}\text { S- } T_{1} \text { depressed, } T_{1} \text { diphasic } \\
S-T_{1} \text { depressed } 4 \mathrm{~mm} \text {. diphasic }\end{array}$ & $\mathrm{S}-\mathrm{T}_{4}$ depressed $1 \mathrm{~mm}$ \\
\hline 14 & $T_{1}$ diphasic & $\mathrm{T}_{1}$ diphasic. (Died suddenly later) \\
\hline 15 & $\mathrm{RS}-\mathrm{T}_{4}$ depressed $4 \mathrm{~mm}$ & RS- $\mathrm{T}_{1}, \mathrm{RS}-\mathrm{T}_{2}, \&$ RS- $\mathrm{T}_{4}$ depressed, \\
\hline 16 & 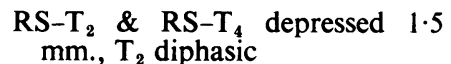 & $\mathrm{RS}-\mathrm{T}_{2}$ depressed $0.5 \mathrm{~mm}$ \\
\hline 17 & $\mathrm{RS}-\mathrm{T}_{4}$ depressed $4 \mathrm{~mm}$ & $\mathrm{RS}-\mathrm{T}_{1}, \mathrm{RS}-\mathrm{T}_{2}, \& \mathrm{RS}-\mathrm{T}_{4}$ depressed \\
\hline 18 & No change & $T_{1} \& T_{2}$ diphasic \\
\hline 19 & No change & $\mathrm{Q}_{2} \& \mathrm{Q}_{3}$ enlarged \\
\hline 20 & RS-T ${ }_{2} \&$ RS-T ${ }_{3}$ depressed $0.5 \mathrm{~mm}$ & $\begin{array}{l}T_{2} \& T_{3} \text { diphasic, slight depression } \\
\text { RS- } T_{2} \& \text { RS-T } T_{3}\end{array}$ \\
\hline
\end{tabular}

\section{Discussion}

In discussing the diagnostic value of the anoxæmia test, it must first be stated that changes in the $\mathrm{T}$ wave and the $\mathrm{S}-\mathrm{T}$ level occur in normal persons if anoxæmia is continued to an extreme degree and long enough. This has been well shown by many observers. Greene and Gilbert (1921), using 6 per cent oxygen, caused collapse, following which there was R-T depression with diphasic and negative $T$ waves, and later, in some cases, an abnormal rhythm. Katz, Hamburger, and Schutz (1933) also found diminution of the T waves, with at times inversion, and also $\mathrm{S}-\mathrm{T}$ depression in normals and in anginal cases. Rothschild and Kissin (1933) took electrocardiograms after induced progressive anoxæmia in 38 persons: 11 developed deviation of the S-T segment; 8 of these suffered from angina pectoris, 3 did not. May (1939) found flattening of the T wave and occasionally a depression of the S-T segment in normals. Stearn, Drinker, and Shaughnessy (1938) described the cardiographic changes in 22 cases following asphyxia from carbon monoxide poisoning; the tracings were 
unfortunately taken only after some treatment with oxygen and carbon dioxide, but 18 showed abnormality of the $\mathrm{T}$ wave and in the level of the S-T segment.

The important fact to be gained from these results is that the anoxæmia was of an extreme degree and very much more severe than that made use of in the test described in this paper. Also most of these other workers obtained anoxæmia by re-breathing, so that it was associated with a progressive carbon dioxide accumulation.

No significant changes of S-T level occurred in our series of controls when 10 or 12 per cent oxygen was inhaled for three to five minutes. Scott and Mullins (1940) caused anoxæmia in cats before and after ligation of the left branch of the left anterior descending coronary artery; changes occurred following anoxæmia only after the artery had been ligated. Larsen (1938), using 9 per cent oxygen, found that the $\mathrm{T}$ wave may be lowered but never inverted, and that the S-T segment was not lowered more than $1 \mathrm{~mm}$. in 20 normals. Levy, Bruenn, and Russell (1939) found in 66 normals using 10 per cent oxygen that the RS-T segment was not displaced more than $1 \mathrm{~mm}$., that the $\mathrm{T}$ wave tends to decrease in amplitude, that in 2 of the $66 \mathrm{~T}$ wave reversal occurred without RS-T deviation, and that partial or complete reversal of $\mathrm{T}$ in leads II or III was observed in 22 of 66 supposedly normal persons. These authors put as their criteria of an abnormal response the following changes: (1) Change in level of the RS-T junction of more than $1 \mathrm{~mm}$. in any lead, its importance being increased if combined with partial or complete reversal in direction of T in leads I or IV F; (2) partial or complete reversal of T in lead I associated with RS-T displacement as small as $0.5 \mathrm{~mm}$. in this lead; (3) complete reversal of $T$ in lead IV F; or (4) partial reversal of $T$ in IV F associated with RS-T displacement. These seem to be the criteria accepted by most authors as an abnormal response to moderate anoxæmia. Larsen (1938) notes that these changes are not pathognomonic of coronary disease, for they may also occur in patients with rheumatic heart lesions, certain endocrine disorders, and severe anæmia.

In comparing the criteria of an abnormal response following anoxæmia with that following the exercise test, Schott (1939) takes as an abnormal response to the exercise test depression of the RS-T segment of more than $1 \mathrm{~mm}$., inversion of a positive $\mathrm{T}$ wave, gross deformation of the $\mathrm{S}-\mathrm{T}$ interval, and diphasic $\mathrm{T}$ waves. Paddu (1938) found only slight change in normals after exercise ; especially RS-T depression of about $1 \mathrm{~mm}$. Other recent papers on anoxæmia and the anginal symptoms are those of Rothschild and Kissin (1933), and of Levy, Barach, and Bruenn (1938). Riseman, Waller, and Brown (1940) cast considerable doubt on the diagnostic value of the anoxæmia and exercise tests -without, in the authors' view, very good reasons for their opinion.

\section{Comparison of Anoxamia and Exercise Tests}

The exercise test appears to give significant changes as often and probably more often than the anoxæmia test, and is much more easily done, as no special apparatus apart from the electrocardiograph is needed. On the other hand, the 
anoxæmia test may show an abnormal change when the exercise test is negative. Also a certain number of patients cannot be persuaded to exercise strenuously.

The response to exercise and anoxæmia in normals and in coronary cases is similar in each test, with this exception: that in normals after the exercise test the $T$ wave tends to be increased in voltage, while after inhalation of 10 per cent oxygen the $T$ wave tends to be reduced in voltage. The increase in voltage after exercise is due, according to Scherf and Boyd (1940), to an increased sympathetic tone. It had been hoped that these tests would give changes conforming to the $T_{1}$ or $T_{3}$ type of coronary curve, so that it would be possible to say which part of the heart was diseased, but only in a few instances did the response give a characteristic localizing change.

\section{SUMMARY}

One-third of all cases with angina of effort show no changes in the four lead electrocardiogram.

Nearly half this group with no cardiographic abnormality give changes suggestive of myocardial disease following anoxæmia with 10 per cent oxygen for three to five minutes or after an exercise test.

The abnormal and normal response to anoxæmia and exercise are described and discussed.

The exercise test gives an abnormal response slightly more often than the 10 per cent anoxæmia test, but changes may occur after anoxæmia when none follow after exercise.

This investigation was carried out in the Cardiographic department of St. Bartholomew's Hospital and more recently at the Royal Chest Hospital, City Road. One of the authors received a grant from the Medical Research Council.

\section{REFERENCES}

Greene, C. W., and Gilbert, N. C. (1921). Arch. intern. Med., 27, 517.

Katz, L. N., Hamburger, W. W., and Schutz, W. J. (1933). Amer. Heart J., 9, 771.

Larsen, Kaj. H. (1938). Iltmangel, Copenhagen.

Levy, R. L., Bruenn, H. G., and Russell, N. (1939). Amer. J. med. Sci., 197, 241.

Levy, R. L., Barach, A. L., and Bruenn, H. G. (1938). Amer. Heart J., 15, 187.

May, S. H. (1939). Ibid., 17, 655.

Paddu, V. (1938). Cardiologia, 2, 183.

Riseman, J. E. F., Waller, S. V., and Brown, M. G. (1940). Amer. Heart J., 19, 683.

Rothschild, M. A., and Kissin, M. (1933). Ibid., 8, 729.

- (1933). Ibid., 8, 745 .

Scherf, D., and Boyd, L. J. (1940). London.

Schott, A. (1939). Guys' Hosp. Rep., 89, 387.

Scott, W. S., Jr., Leslie, A., and Mullins, M. G. (1940). Amer. Heart J., 19, 719.

Stearn, W. H., Drinker, C. K., and Shaughnessy, T. J. (1938). Ibid, 15, 434. 